\title{
Culture Jamming Phenomenon in Politics (The Jokowi's Memes in TIME Publication's Cover and TokoBagus.com Advertisement)
}

\author{
Pinckey Triputra \\ University of Indonesia, Jakarta, Indonesia \\ Fievielia Sugita \\ Tarumanagara University, Jakarta, Indonesia
}

\begin{abstract}
Culture jamming is the result of post-modernity movements characterized by social criticism and resistance to things related to modernity. The intent is to subvert symbols and meanings or to counter hegemony. Besides, it critiques the media manipulation of reality and questions corporate power. It demarkets news, entertainments, lifestyles, and desires in human's daily loop of consumerism. This activism is similar to the concept of noise in communication model by Shannon and Weaver. The intent is to alter political contents by defacing symbols to reconstruct meanings that undermine advertisers' intention using communication technology. As a result, the target will receive new meanings in cultural or political perspectives. Culture jamming phenomenon in politics can be found in the form of meme, media hoaxing, hacking, and Adbusters. Asides from the anti-marketing "consumerism" phenomena, the aim of paper is to show meme forms as the basic units of culture jamming which have emerged in one year regime of Jokowi. First meme that reconstructed Jokowi in TIME publication's cover was issued in October 2014. And the second meme reconstructs Jokowi as the object of Tokobagus.com advertisement. These memes are used to be a new medium of critics and also an effective tool for binary opposition in defacing political issues.
\end{abstract}

Keywords: culture jamming, interference (noise), political critics, meme, post-modernity

This paper tries to show different perspective phenomenon as what culture jamming embeds in advertising and marketing concepts to consumerism. It is the Indonesia political phenomenon which happened in 2014 as the biggest democracy summit. Within a year, Indonesia has held two elections: the elections for the members of House of Representatives (DPR RI) in April and the seventh election of President and Vice President in July. This phenomenon has brought Indonesia into subtle and brand new political challenges since Joko Widodo (Jokowi) and Jusuf Kalla (JK) took the lead. Therefore, bunches of sinister critics from binary opposition have bursted out in public within one year after their vow as becoming the seventh President of Indonesia.

Those critics are derived from disappointments currently shown in cyber media using culture jamming technique. According to Wettergren (2005, p. 42), culture jamming is a symbolic form of protest that targets

Pinckey Triputra, Ph.D., University of Indonesia, Jakarta, Indonesia; research field: political communication.

Corresponding author: Fievielia Sugita, B.Sc., Tarumanagara University, Jakarta, Indonesia; research field: political communication. 
central symbols of dominant discourses, deconstructs the discourses, and reintroduces the symbols in alternative contexts.

According to Mohan J. Dutta (2011), the basic unit in culture jamming is meme. Memes are condensed images that stimulate visual, verbal, musical, or behavioral associations that people can easily imitate and transmit to others. This core unit of cultural transmission contains sarcastic words, irony, cynicism, or jokes. Culture jamming through meme has brought a new transformation in political perspective to give critics and aspirations or other activism with the sense of humor. The criticisms arising in publics are the reconstructive results of meanings and signals conveyed by political actors, which are such interesting new studies to be discussed. This is because visual medium such as pictures and photos with the sense of humor of popular political icons is likely to attract public's attention in case to stimulate the consciousness visually and verbally.

The nature of viral meme by spreading ideas and culture phenomenon in person via online to criticize political issues is easier and more understandable in public sphere. Compared to media hoaxing and hacking, the viral nature of meme is superior to represent and reconstruct meanings because it can create a space in social media to express criticisms. In addition, meme has an implicit notion to capture the irony or blasphemy from social phenomenon in public through Internet. Therefore, it can be effectively used as a tool for binary opposition to counter political contexts from apparatus.

This paper discusses the reality of culture jamming phenomenon in politics using the meme forms. They involve two phenomenal Jokowi's memes which have emerged within a year under his regime such as in TIME publication's cover and Tokobagus.com advertisement. Culture jamming is a reality of protest happened from diverse opinions of binary opposition by bombarding manipulated pictures and refigured logos or symbols to mislead public views. The purpose of this paper is to apprehend and to show the "uncool" reality of culture jamming phenomenon in politics by using two memes which had emerged within a year of Jokowi's regime.

\section{Literature Review}

\section{Post-modern Era}

Post-modernist Charles Jencks proposed that the main concept of post-modernism is the birth of information era. The post-modernism has paralleled and confided in transition of information age. The post-modern era directs the focus on the information which computer is the symbol of transition from industrial to the information society. The modern era which had produced industrial society has now stepped into a post-modern style adopting the pluralism mindset. Therefore, the production of homogenous goods has deformed into heterogenous goods. This can be characterized by how to dress well in which equality against the color, style, and fashion is no longer needed to obey. The main unit in post-modern era is human as identity. The specified identity is how humans live and look at their own in post-modern life. In the nature of human freedom, modernists live up as what human being says and does. However, post-modernists live freely as long as when no one is able to tell how to live (Jones, 2009, p. 226).

The other post-modernist, Jean Baudrillard questioned the reality concept called as "hyper-reality". This concept explains that everything will be a reference (the result of the construction of media) meanwhile not everything necessarily referred will be the description in reality. Jean Francois Lyotard simplified post-modern concept as an incredulity towards meta-narration. On the other hand, Jasques Derrida proposed the concept of "Deconstruction". This concept defines the process of tracing meaning that is escaped from dichotomy presences and stories about inary opposition (Fansuri, 2012, p. 34). 
Littlejohn and Foss exposed that post-modernism is based on the idea of social reality which is still produced, reproduced, and modified with the usefulness of language and other forms or symbols (Littlejohn \& Foss, 2009, p. 477). The post-modern reality especially in political aspects shows new communication form in condensed images. One of the examples is the fiction humor Mice Cartoon (see Figure 1) which can be read every Sunday edition of Kompas newspaper.

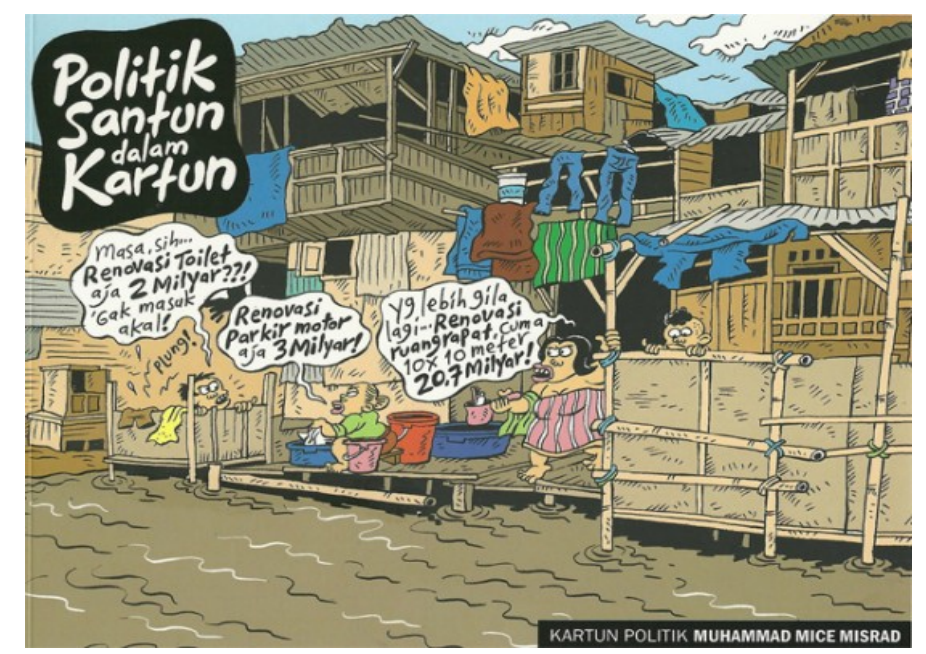

Figure 1. Mice Cartoon as political critics in post-modern (source from online micecartoon.co.id).

The cartoonist Mice describes the reality of political conditions in Indonesia with the sense of humor and irony. This cartoon is a simple way to observe all cases of politicians by inserting his point of view or public's perspective. He makes this cartoon as the platform for new political activities in giving public comments against authorities or political issues.

This new form of post-modernism can be easily found by using commmunication technology. Latest devices for information communication have revolutionized the inseparable connection between human and technology. Rogers (1999) defined communication technology as a hardware, organizational structure, and social value in which one collects, processes, and shares information to others. Technology could not be defined merely as hardware yet as a system of social institutions and values to support its technology inventions (Rogers, 1999, p. 23).

Mass media existence along with the advance of communication technology has brought the power to change the way humans interact. Life and culture are no longer shaped by nature yet by an electronic mass media environment. McLuhan argued that technology inevitably causes specific changes in how people think, how society is structured, and how the forms of culture are created. He also give assumptions when new media technologies were introduced into society, the balanced senses were reworked, highlighting some at the expense of others (Baran \& Davis, 2012, p. 271).

\section{Culture Jamming}

Eversince living in information era, global societies communicate accessibly both in sending and receiving messages. This also has transformed them in every aspect of life, including political aspects. Due to easy, broad, and quick access of information, it provides a wide range of opts in choosing capitalism goods or services in market competition. Diverse attractive products make societies move to be private consumers in sorting out types of contents over consumerism arising involuntarily in many kinds of commercial advertising in media 
channels. According to Handelman and Kozinets in Carducci (2006, p. 116), culture jamming is defined as an organized, social activist effort that aims to counter the bombardment of consumption-orieted messages in the mass media.

Kalle Lasn (1999) defined that culture jamming is at root, just a metaphor for stopping the flow of spectacle long enough to adjust your set. Stopping the flow relies on an element of surprise. It shows a new path replacing with a new one. The new syntax carries the instrutions for a whole new way of being in this world. Unlike Lasn, Mohan J. Dutta (2011) defined culture jamming as an intriguing form of political communication that has emerged in response to the commercial isolation of public life. Practitioners of culture jamming argue that culture, politics, and social values have been bent by saturated commercial environments solely to deliver targeted audiences to producers and sponsors (Dutta, 2011). Like moths to flame, Wettergren (2005, p. 42) stated that culture jamming as a symbolic form of protest targets central symbols of dominant discourses, deconstructs the discourses, and reintroduces the symbols in alternative context. Culture jams refigure logos, fashion statements, and product images to challenge the idea of "what's cool", along with assumptions about the personal freedoms of consumption (Wettergren, 2005).

In this way, a perverted sense of cool takes hold of the imaginations of childern. "Cool" is highly addictive and its effects are short-lived. Humour and jokes are structured as powerful weapons for criticizing. Culture jammers are seized by a similar sense of urgency to do something to escape the consumerist script. To culture jammers, such knowledge and skill are central ingredients and preconditions for protest; it will change the way we interact with the mass media and the way in which meaning is produced in our society (Carducci, 2006).

\section{Political Communication}

Cangara (2011, p. 30) explained that political communication is the process of transferring codes or symbols of communication containing a political message from a person or group to another with the purpose of enlightening a new way of thinking and influencing the attitude and behavior of the political target. The political communication needs a necessary amount of media in order to process its contents, such as printed media, small media format, outdoor media, and electronic devices.

In the printed media, political messages can be found in newspapers, tabloids, magazines, and books. Meanwhile small formatted media can be seen as leaflets, brochures, flyers, stickers, and newsletters. The political message printed in outdoor media can be seen in the form of billboards, banners, electronic boards, flags, tassels, pin, logo, hats, T-shirts, and advertisement on a car or anything that could be used to create "image building". Whilst the electronic media can be accessed through film, radio, television, video, computers, and Internet.

\section{Culture Jamming Reality in Politics}

In culture jamming reality, humor plays an important role in which fun and pleasure is the emotion in a new form of protest. Humor is an attempt of expressing satire, blasphemy, and irony towards the political issues and events. Culture jamming is seen as an investigation into the apparatus of representation in late modernity, as it relates to both images and discourses of the media and the commodity system, and the expression of political will (Carducci, 2006, p. 116). Political humor (in Cangara, 2011, p. 296) has emerged as public needs to give critics. Culture jamming is a new effective way to share aspirations, express ideas, or criticize politicial issues or other forms of political associations. One example of the political critiques in culture jamming is a political meme of Barack Obama (see Figure 2) which had emerged during America's election. This meme 
presents the parody in the form of pictures or photos containing criticism or blasphemy and can be accessed via Internet.

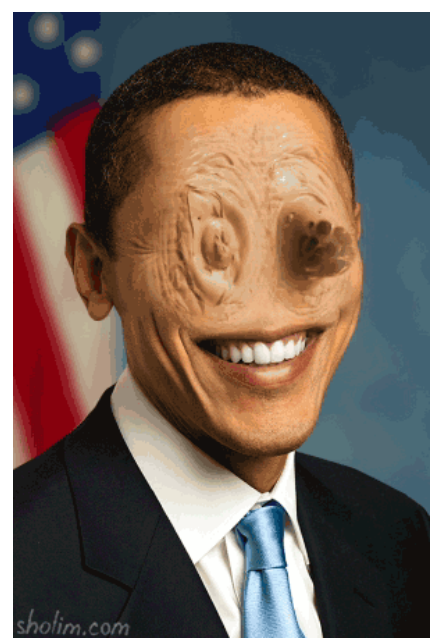

Figure 2. Culture jamming of Obama portray picture (source from online 24.media.tumblr.com).

Another example of reconstructing political issues is the show in TV programs such as Indonesia Lawak Club (ILK) that aired in Trans7 five times a week, Monday-Friday at $6 \mathrm{pm}$ onwards. It is a political parody program from the show Indonesia Lawyers Club which aired TVOne criticizing national issues. Another model is the program named Democrazy aired in MetroTV every Sunday, at 9 pm as platform discussion by impersonating Indonesia's irony in political aspects.

\section{Culture Jamming Reality in Phenomenon}

In the nature of human's communication process, there will always be interferences or noise to distract the contents of messages. This can be explained with a noise model of communication. This model was conceived by Claude Elwood Shannon and Warren Weaver. According to Severin and Tankard Jr. (2009, p. 60), noise is an additional signal unneeded for information sources. Other practitioners further expand this concept into four different types: psychological noise, physical noise, semantic noise, and interference in media and environment for receiver (Severin \& Tankard Jr., 2009).

Culture jamming is similar to the concept of noise model of communication derived by Shannon and Weaver. It emerged as an interference with effective transmission and reception of a message to reconstruct signals and to inject new ideas into public sphere. During transmission process, jammers interfere with the signals through the same media by criticizing and reconstructing the "cool" message with a sense of humor, resulting in the destination (receiver) obtaining the reconstructed model of the message. Culture jamming can also be analyzed as an instance of political activism departing from the thematic structure, place, and identity. Culture and identity become increasingly important in all spheres of the information society, partly as a consequence of an expanding consumer culture. The political reality in culture jamming phenomenon can be observed in meme, media hoaxing, hacking, and Adbusters.

Meme: the basic unit of communication in culture jamming. The English evolutionary biologist and author Richard Dawkins first proposed the term "meme" (based on the Ancient Greek word mimema meaning "something imitated"). Dawkins defined memes as small active cultural units of transmission which are spread from person to person, spanning from language to conventions of football, by copying or imitiating (Börzsei, 
2013, p. 3). Lasn (1999) mentioned that it can be found as a catchphrase; a concept; a tune; and a notion of fashion, philosophy, or politics that leap from brain to brain. In addition, Dutta (2011) defined that memes are condensed images that stimulate visual, verbal, musical, or behavioral associations that people can easily imitate and transmit to others. Meme may spread in its original form, but it often also spawns user-created derivatives (Dutta, 2011).

Media hoaxing: something intended to deceive or defraud. Media hoaxing is defined as a prank made by jammers to deceive journalists by publishing false issues or perturbing corporate media (in Nomai, 2008, p. 27). Hoax usually emerges in order to spread falsities and social ironies by representing objects and logos along with current issues. One of the methods used to spread hoax is through making fake website. The fake website of personal or other institutions tends to be created to publish critics. GWBush.com is one of fake websites that emerged in 1999 due to US presidential election. This site is an example of fake websites of georgewbush.com which consists of harsh contents and falsehoods.

Hacking: Hacking is used to disrupt services and is a tool in raising awareness of a new kind of Internet threat. Hacking is increasingly being used as a weapon by individuals to promote their political ideologies by engaging in distributed citizen-based warfare and online assaults. Hacktivists use malicious software to subvert messages (Heran, Mahncke, \& Williams, 2009). Each progression of hactivism is always considered to be illegal and unethical. It can also be referred as digital activism, electronic civil disobedience, or cyber terrorism where political motive is to create loss of life and economic havoc. Its actions depend on who is doing the backing and to whom.

Adbusters: The biggest not-for-profit and anti-consumerist organization for active jammers both in print and online media. Adbusters was founded in 1989 by Kalle Lasn and Bill Schmalz, a duo of award-winning documentary film makers in Vancouver, British Columbia, in 1989 (Lasn, 1999). Adbusters takes big risks in which every authentic action tends to get noticed that postmodern culture thrives. This foundation believes large corporations control mainstream media and its flow of information and culture jamming aims to challenge them as a form of protest. Adbusters reconstructs fashion, celebrities, and other for-sell-America-logos becoming uncool through nonconsumption strategies by demolishing its brand images. Thus, this foundation is called as one of culture jamming forms. The foundation's activism is particularly well known for its culture jamming campaigns through magazine and advertisement vandalism spread in American regions and social marketing campaig through Powershift advocacy advertising agency (Lasn, 1999).

\section{Meme in the Advance of Communication Technology}

The platform of Internet has helped to change the ways of accessing and locating information in the modern information society. McLuhan assumpts that changes in communication technology inevitably produce profound changes in both culture and social order (Baran \& Davis, 2012, p. 407). Marshall McLuhan gives an assumption "The Medium Is the Message". It means that the form of a medium embeds itself in the message and influences us on how the message is perceived. He believes that we should observe not only the medium itself but also the ways in which each new medium disrupts tradition and reshapes social life. Through Internet, aspirations are now spread in types of forms, including Internet meme.

Internet has provided new frontier to challenge political ideologies. The term Internet meme refers to the phenomenon of content or concepts that spread rapidly among Internet users. It typically evolves through commentary, imitations or parodies, or even through related news in other news. As of late, the phenomenon of 
Internet memes has attracted growing public interest (Bauckhage, 2011, p. 42). With the emergence of the Internet, meme was also applied to contents that spread from user to user online. The Internet meme is a form of visual entertainment, which can manifest in many different formats, such as a still image, an animated GIF (Graphic Interchange Format), or even a video (Börzsei, 2013, p. 5).

Meme is currently applied as new political tool for criticising and expressing ideas and aspirations with the sense of humor. The reality of meme politics is depicted in a parody way which consists of jokes and rumors via media Internet. Political campaigning increasingly attempts to create Internet memes to shape opinion. They are supposed to create an image of trendiness, but often interest in the content is for purposes of trivia or frivolity rather than for information (Bauckhage, 2011, p. 42). Potent memes can change minds, alter behavior, catalyze collective mind shifts, and transform cultures.

\section{Research Methodology}

This research analyzes the phenomenon using qualitative approach. Qualitative method used for this paper is exploratory to seek for clearer background of the subject or phenomenon because there is no any hypothesis yet or any latest research made (Soentoro, 2015, p. 11). Data collected in this research are derived from online media. Data research results are analyzed using the semotics analysis of Roland Barthes. According to Barthes (in Sobur, 2009, p. 123), semiotics is not only researching about signifier and signifying a form but also finding relationships of related signals as a whole sign. He concerns on two orders of signification i.e. the concept denoted as cultural products in the first stage and connotation as a second stage which uses the denotative sign as its signifier and attaches to it an additional connotation. The first stage is seen primarily representational and relatively self-contained. The second stage reflects expressive values which are attached to a sign. Whereas, signs and codes are generated by myths in turn serve to maintain them (Sobur, 2009).

\section{Research Results}

\section{Observation Unit Overview}

Culture jamming phenomenon uses two memes to depict political reality. This is used to interrupt the flow of "what's cool" images and information portrayed in media. Meme has the viral nature spreading ideas or cultural phenomenon through Internet communication technology. It is a cool tool to rebel as its units contain sarcasm, irony, or cynical/dark jokes. Meme has brought a new transformation in political sphere to send messages because its content consists of humor and has become the new entertainment for the message recipients. The meme contains subvertised catchphrases, concepts, tunes, and politics that leap from brain to brain to drop the credibility of political actors via sarcastic, ironic, cynical, or dark jokes.

\section{Analysis and Discussion}

Months after Jokowi's election, both praises and critics emerged in national and international media. Binary opposition was using memes as a "cool" tool to turn down good vibes of his regime. The first meme is the reconstruction result of the Jokowi's portrait in TIME publication's cover. The second meme is the reconstruction display of Tokobagus.com which contains Jokowi as the advertisement.

Media dissemination: Conventional media forms (as denotation) are combining with new ones in ways that change our media consumption patterns, our lives, and the societies in which we live. Conventional media as to spreading political messages use visual media, audio and audiovisual. However, the new technology communicaton has brought new spread transformation into a new medium (connotation). Internet, as a 
replicating medium, has become an integrated transmission for political actors whereas all messages can be accessed for free across nation. New media are more effective to attract attention and disseminate political criticisms. New media have two-way communication characteristic providing feedback for public to comment and voice their responses. People can upload videos, pictures, and photos without charge through Internet.

Meme as new political critics medium: This emerges as an interference (noise) similar to a model of communication according to Shannon and Weaver. It comes as a concept that leaps from brain to brain transforming critics through jokes. Interference contains reconstruction results of images or videos of political actors, issues and other political associations created by jammers which can bring joy, laughter, and jokes for readers. This is the basic unit of culture jamming phenomenon. Meme came up due to the encouragement of social criticism and rejection of strong resistance from different views of binary opposition: communicator and communicant. This explains how communicator is able to convey meanings and the ability of communicant to interpret and find meanings of its metaphor therein. In addition, the nature of viral meme creates a new space to express ideas through media technology.

The political reality through meme in culture jamming phenomenon is seen in Table 1: This study case is to apprehend memes as new media critics in one year regime of Jokowi as the rage of protest.

Table 1

Denotation and Connotation Meme of Jokowi in TIME Publication

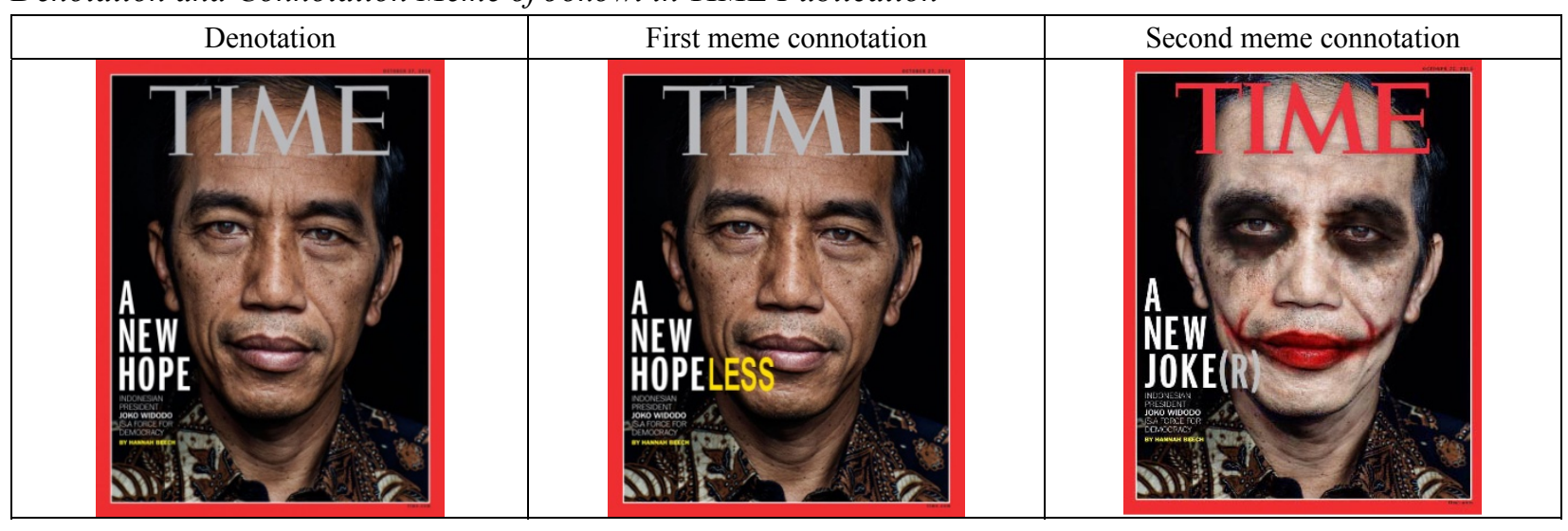

Analysis: Protest actions in general can be found in conventional media as their medium, such as newspapers, magazines, radio, TV, and extra. Newspapers print lots of letters of protest/critics to the editor, radio talk shows debate the current issues of the days. Yet through the new medium, culture jamming can be found in any kinds of transmission units, including publication's cover.

The first meme reconstructs TIME's catchphrase of its October edition in 2014- “A New Hope". It subverts negation "-less" added on the word hope and thus creating new meaning as despair and no hope. In addition, the headline also gets reconstructed with yellow color on the term "-less". Yellow is chosen because it is considered as prominent sign to catch public's attention and can increase the concentration in order to understand the meaning of the word which has been reconstructed ${ }^{1}$. Meanwhile, the second meme also gets reconstructed into red color and has the connotation meaning as a warning or an alert that we had to be aware of Jokowi's new democracy for Indonesia. Besides logo color, there lies within a double-rhyming catchphrase

${ }^{1}$ Retrieved from http://nasional.kompas.com/read/2008/10/09/15551015/psikologi.dan.arti.warna. 
reconstruction: A NEW JOKE and A NEW JOKER. We divide them into two contexts, such as social and predicate. In social context, Jokowi is connotated as the object of Indonesia's jokes. The meme maker criticizes his winning as the seventh president although he has no military background and is the gangly son of the slums from Solo. Meanwhile, in predicate context, Jokowi is interpreted into three figures, such as a comedian, Joker in a playing deck card, and Joker in The Dark Knight film.

The metaphor of Jokowi (see Table 2) as a comedian is meant as the ironic figure who is not seriously ruling Indonesia. The connotation of Joker in the playing deck card is meant as Megawati's backup man to order him fight for the seventh presidential election 2014-2019 because of his high popularity gained from public. The last reconstruction is similar to Joker character in The Dark Knight. Joker acts as a psychopath with high intelligence and as the strongest enemy of Batman. Jokowi is similar to this figure because of his winning against Prabowo Subianto who has military background, is genius and unpredictable, and acts like attending the groundbreaking of a subsidized-housing development.

Table 2

Denotation and Connotation Meme of Jokowi as Tokobagus.com Advertisement

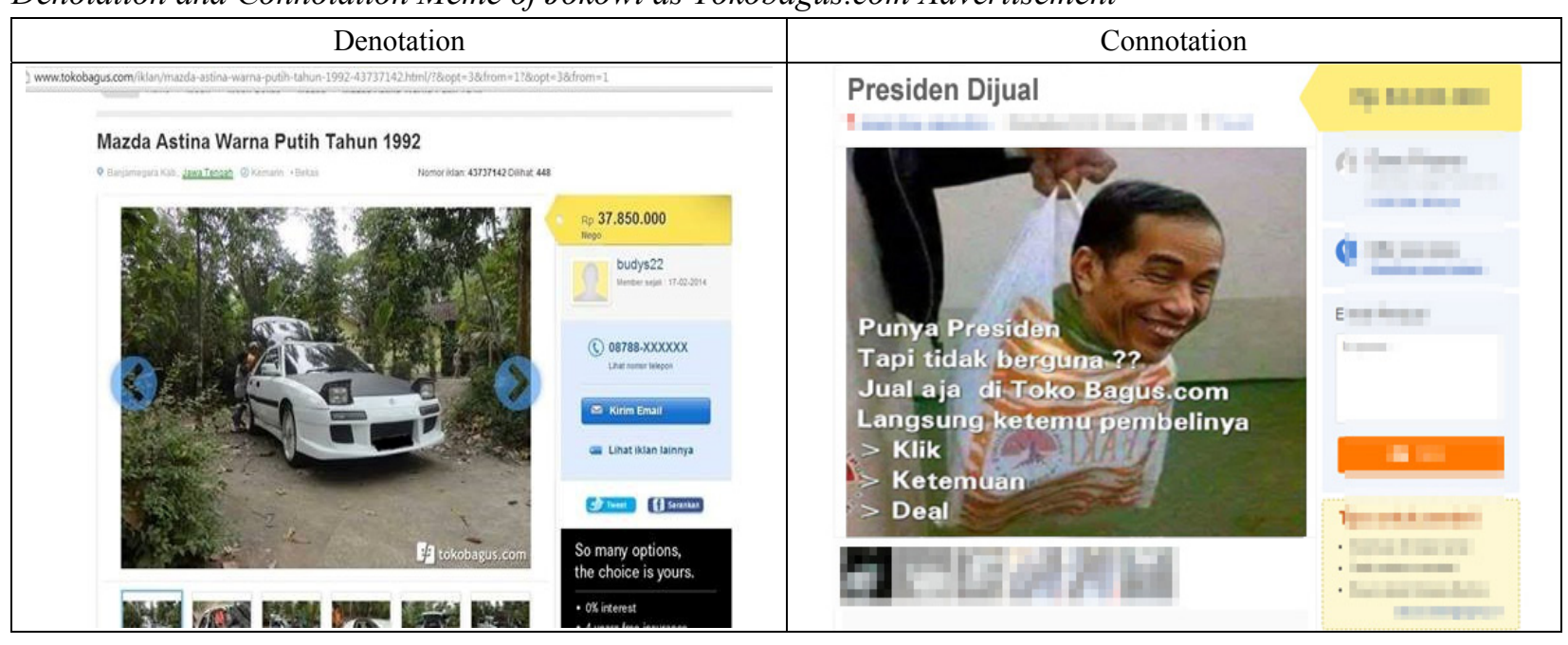

Analysis: This meme is created by Mansyorie Lamp and spread through Facebook. It subverts the display of Tokobagus.com (now OLX.co.id) by cropping Jokowi's smile expression and adding him a plastic bag below his head. He tried to counter the bombardment of consumption-oriented messages through e-commerce by issuing political issue of Jokowi's regime. His expression (see Figure 3) is documented by Tempo media photo journalist when he once came to its newsroom on January 14, 2013.

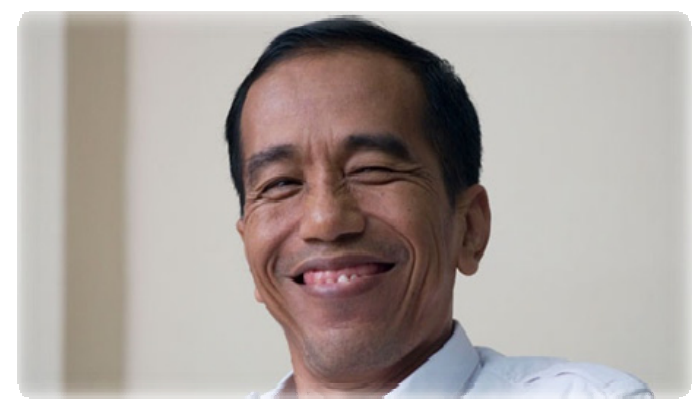

Figure 3. Jokowi's photo expression (source from online media at Tempo.co). 
This criticism has become a phenomenal issue when the meme maker Mansyorie is almost gotten imprisoned. He was using Internet to gain immediate access to millions of people and was considered breaking the law of humiliating president. In connotation, Jokowi is figured as futile item and is on sale for public through a thrift online marketplace, Tokobagus.com (now OLX.co.id). It (denotation) is one of the largest classified ads sites in Indonesia selling pre-loved items to enhance their company profit using the catchphrase "Cara Tepat Jual Cepat". It is more commonly used by Indonesians to conduct C2C e-commerce and trading activities online.

\section{Conclusions}

Along with a highly developing communication technology, criticism in political aspect can be transfered through a new medium. This is based on a shifting culture of modernism which exposed the concepts of universality, harmony, and consistence into a post-modern era. Post-modernists live in a new way of thinking and seeking for diversities. This phenomenon is the result of post-modernist movements characterized by the existence of social criticism and opposition to all forms of modern styles. It demarkets news, entertainments, lifestyles, and desires in human's daily loop of consumerism. Criticsm or satires are caused by different understanding of meanings and strong political resistance from binary opposition between promise and reality on the ground. Culture jamming movement tries to discover the "uncool" and change the mindset of a person by reconstructing meanings of signals and defiguring symbols or logos which are produced by dominant groups in order to create a new meaning of social, cultural, and political values. In political reality, this phenomenon can be observed in the form of meme, media hoaxing, hacking, and Adbusters.

In political action, culture jamming appears as an interference which is similar to noise model of communication by Shannon and Weaver. It reconstructs signals, disrupts meanings, and injects new values during transmission process. Its movements use the same existing forms and channels but deflect the true meaning. This new medium expresses irony of current political issues, and contains humor therein.

Meme is the basic unit of communication in culture jamming, which uses condensed images as its medium consisting of humor, blasphemy, or sarcasm. Political meme can be effectively used as a tool for binary opposition because of its understandable and easier visual look. Besides, the nature of viral meme by spreading ideas and culture phenomenon through Internet connection serves two-way communication access (feedback). Therefore, it creates a new space for public sphere to express ideas or aspirations freely and quickly in no time. This paper discusses the political reality of culture jamming phenomenon by apprehending two memes which had emerged within a year of Jokowi's regime.

\section{References}

Adbusters.org. (2016). Adbusters: About. Retrieved from www.adbusters.org/about/adbusters

Anam, K. (2010). Hacking VS Islamic law and positive law. Yogyakarta: Sunan Kalijaga Press.

Baran, J. S., \& Davis, D. K. (2012). Mass communication theory: Foundations, ferment and future. California: Wadsworth Publishing Company.

Bauckhage, C. (2011). Insights into internet memes. Germany: Fraunhofer IAIS.

Börzsei, L. (2013). Makes a meme instead: A concise history of internet memes. Netherlands: Utrecht University.

Cangara, H. (2011). Komunikasi politik: Konsep, teori, dan strategi (Political communication: Concept, theory, and strategy). Jakarta: Rajawali Pers.

Carducci, V. (2006). Culture jamming: A sociological perspective. Journal of Consumer Culture, 6(1), 116-138. New York City: Sage Publication. 
Dutta, M. J. (2011). Social change: Structure, culture, and agency. London: Routledge. Retrieved from http://www.globalmedia journal.de/2011/12/12/review-communicating-socialchange-structure-culture-and-agency/

Fansuri, H. (2012). Islamic sociology journal: Globalization, postmodern and new sociology challenge in Indonesia. Year 2012, vol. 2, no. 1. Retreived from http://jsi.uinsby.ac.id/index.php/jsi/article/view/17

Heran, K., Mahncke, R. J., \& Williams, P. A. (2009). Culture jamming: From activism to Hactivism. Australia: Edith Cowan University.

Jones, P. (2009). Introducing social theory (1st ed.). Cetakan pertama. Jakarta: Yayasan Pustaka Obor Indonesia.

Lasn, K. (1999). Culture jam: How to reverse America's suicidal consumer binge-And why we must. New York: The Quill.

Littlejohn, S., \& Foss, K. (2009). Theories of human communication (9th ed.). Jakarta: Salemba Humanika.

Nomai, A. J. (2008). Culture jamming: Ideological struggle and the possibilities for social change. The University of Texas: Not for public publication.

Rogers, I. (1999). The social construction of technology and the development of satellite telecommunication in Indonesia in political and cultural society. Th. XII, no. 3, Juli 1999, pp. 23-30. Posted in February 11, 2009.

Severin, W. J., \& Tankard Jr., J. W. (2009). Communication theories: Origin, methods and uses in the mass media. Jakarta: Kencana Prenada Media Group.

Sobur, A. (2009). Media text analysis. Bandung: Remaja Rosdakarya.

Soentoro, A. I. (2015). Easy way learning research methods with statistical analysis. Depok: Taramedia Bakti Persada.

Straubhaar, J., \& LaRose, R. (2008). Media now: Understanding media, culture, and technology. USA: Thomson Higher Education.

Wettergren, A. (2005). Moving and jamming-implications for social movement theory. Doctoral dissertation, Department of Sociology, Karlstad University. 